Fournal of Medical Genetics (1971). 8, 143.

\title{
Genetics of Childhood Spinal Muscular Atrophy
}

\author{
ELIZABETH J. WINSOR,* E. GORDON MURPHY, MARGARET W. THOMPSON, \\ and T. EDWARD REED
}

\begin{abstract}
From the Departments of Zoology and Paediatrics, University of Toronto, and the Neurological Service and Department of Genetics, Hospital for Sick Children, Toronto, Ontario, Canada
\end{abstract}

Spinal muscular atrophy (SMA) is a disease, or group of diseases, of the anterior horn cells of the spinal cord, in which there is widespread atrophy of muscles secondary to anterior horn cell degeneration. Though the characteristic neuronal degeneration can be determined directly only by necropsy, the secondary changes in the skeletal muscle detectable by electromyography and muscle biopsy are so specific that the diagnosis poses no serious problem. However, the classification and genetics of SMA are still under discussion (Research Group on Neuromuscular Diseases, 1968; Zellweger et al, 1969). Though most authors agree that all SMA is genetically determined, it is not yet clear whether it is a single entity, in which action of the same mutant gene or gene pair against a variety of genetic backgrounds produces the variability observed in onset age, clinical course, and life span, or whether there is genetic heterogeneity (several diseases with similar or overlapping phenotypes, determined by different mutant genes). In particular, doubt remains as to whether the two main forms presenting in childhood, the infantile Werdnig-Hoffmann form (Werdnig, 1891; Hoffmann, 1892) and the juvenile, clinically milder Kugelberg-Welander form (Kugelberg and Welander, 1956), represent different expressions of the same mutant gene or are genetically distinct. The question as to whether all cases are autosomal recessive or whether some are autosomal dominant with reduced penetrance, or even nongenetic phenocopies, is also unresolved.

The purpose of this report is to describe a genetic analysis of 91 cases of childhood SMA, with special reference to incidence, genetics, parental age, birth rank, and variation of clinical expression within families. These data are used to determine whether the Werdnig-Hoffman and KugelbergWelander forms of SMA are always genetic and, if

\footnotetext{
Received 4 May 1970.

* Present address: Department of Paediatrics, Dalhousie University, Halifax, Nova Scotia, Canada.
}

so, whether all cases fit autosomal recessive inheritance. A search was made for evidence of genetic heterogeneity and of the existence of phenocopies.

\section{Materials and Methods}

The 91 children used in the present study were selected from patients seen at the Hospital for Sick Children, Toronto, Canada, during the period 1950-1967. Atypical or inconclusive cases were omitted. Three cases not seen at the Hospital were included, on the basis of the hospital records of their affected sibs. Information about the patients and their families was obtained from the hospital records (including the records of the Genetics Department) and was supplemented by personal interview (20 families), questionnaire (20 families), and a direct inquiry to referring physicians. For certain control data, the Ontario reports on Vital Statistics for 19551965 were employed.

\section{Results}

Frequency and prevalence. To estimate the population frequency of SMA, a 14-county area surrounding the city of Toronto was used. Ascertainment of this area should be virtually complete, whereas patients living outside this area might be referred to other paediatric centres.

Table I shows the population and live birth estimates, and Table II the number of births, new cases, existing cases, and deaths of patients with SMA in the ascertainment area in the years between 1955 and 1965. The estimated frequency of births of affected children was approximately 6 cases per 100,000 live births. The average number of new cases detected per year was $3 \cdot 5$. Using $2,522,147$ as an estimate of the total population of the area (see Table I), the estimated frequency of new cases per year is 1.4 per million population ( $95 \%$ Poisson confidence interval $0 \cdot 3-3 \cdot 8$ per million).

The prevalence of the disease, or the number of cases in the population at any given time, is shown in Table III. Prevalence was estimated for intervals 
of three years, on the basis of the population of the middle year of the period. This method yields a prevalence estimate of 7.4 per million ( $95 \%$ confidence interval 4.4-11.6 per million). Comparison of the number of patients alive in each year from 1956 to 1965 suggests a tendency for an increase in prevalence. This apparent increase may be due to increased life span through improved therapy. Increased likelihood of detection of the disease or of referral of affected children to this hospital would also cause an apparent increase.

TABLE I

POPULATION AND LIVE BIRTH ESTIMATES FOR ASCERTAINMENT AREA,* TAKEN FROM PROVINCE

OF ONTARIO, VITAL STATISTICS

\begin{tabular}{l|c|c}
\hline \multicolumn{1}{c|}{ Year } & Total Population & Live Births \\
\hline 1955 & $2,100,300$ & 55,784 \\
1960 & $2,533,040$ & 67,250 \\
1965 & $2,933,100$ & 62,222 \\
Average & $2,522,147$ & 61,752 \\
1955-1965 & 2,522, & \\
\hline
\end{tabular}

* The ascertainment area is a 14-county section of Ontario which includes these counties and districts: York (including Toronto), Peel, Simcoe, Sudbury, Parry Sound, Nipissing, Muskoka, Ontario, Victoria, Haliburton, Peterborough, Northumberland, Dufferin, and Durham.

\section{TABLE II}

ANNUAL DATA ON CASES OF SPINAL MUSCULAR ATROPHY: BIRTHS, DETECTION, NUMBER LIVING, AND DEATHS

\begin{tabular}{c|c|c|c|c}
\hline Year & $\begin{array}{c}\text { Births of Cases } \\
\text { Diagnosed Later }\end{array}$ & $\begin{array}{c}\text { New Cases } \\
\text { Detected }\end{array}$ & $\begin{array}{c}\text { Number } \\
\text { Living }\end{array}$ & Deaths \\
\hline 1956 & 4 & 2 & 14 & 4 \\
1957 & 2 & 3 & 13 & 2 \\
1958 & 7 & 6 & 17 & 4 \\
1959 & 2 & 4 & 15 & 1 \\
1960 & 5 & 4 & 21 & 5 \\
1961 & 3 & 1 & 17 & 0 \\
1962 & 0 & 5 & 20 & 1 \\
1963 & 3 & 5 & 27 & 2 \\
1964 & 7 & 35 & - & 25 \\
1965 & 4 & & & \\
\hline Total & 37 & & &
\end{tabular}

TABLE III

PREVALENCE OF SPINAL MUSCULAR ATROPHY IN ASCERTAINMENT AREA, 1956-1964

\begin{tabular}{c|c|c|c}
\hline Period & $\begin{array}{c}\text { Average Number } \\
\text { of Probands }\end{array}$ & Population & Prevalence \\
\hline $1956-1958$ & $14 \cdot 7$ & $2,315,460$ & $6.3 \times 10^{-6}$ \\
$1959-1961$ & $18 \cdot 0$ & $2,333,040$ & $7 \cdot 1 \times 10^{-6}$ \\
$1962-1964$ & $20 \cdot 3$ & $2,748,500$ & $7 \cdot 4 \times 10^{-6}$ \\
\hline
\end{tabular}

\section{Genetics}

Segregation analysis. Table IV lists the sibships used for determination of the segregation proportion. On the assumptions that SMA is determined by homozygosity for a rare autosomal recessive gene and that ascertainment is complete, the a priori method of analysing the data is appropriate. The expected number of affected sibs and variance for various sizes of sibship have been calculated using Hogben's method (Hogben, 1946).

Table $\mathrm{V}$ gives the segregation proportions in the sibships from four points of view. First, the total group of sibships was tested. The segregation proportion of sibships within the ascertainment area was then calculated, as a check on the method of ascertainment. Next, because of the suggestion that the more severe forms of the disease are recessive and the less severe forms incomplete dominants (Becker, 1963), the sibships were divided into two categories on the basis of survival, ie, into two groups, one having an affected individual who lived for less than 2 years and a group having an affected individual who survived for more than 5

TABLE IV

TABULATION OF SIBSHIPS FOR DETERMINATION OF SEGREGATION PROPORTIONS

\begin{tabular}{|c|c|c|c|c|}
\hline \multirow[b]{2}{*}{$\begin{array}{l}\text { Sibship } \\
\text { Size }\end{array}$} & \multicolumn{4}{|c|}{ Number of Sibships } \\
\hline & $\begin{array}{l}\text { Total } \\
\text { Data }\end{array}$ & $\begin{array}{c}\text { Ascertainment } \\
\text { Area }\end{array}$ & $\begin{array}{c}\text { Containing } \\
\text { a Child who } \\
\text { Lived } \\
<2 \text { years } \\
\end{array}$ & $\begin{array}{c}\text { Containing } \\
\text { a Child who } \\
\text { Lived } \\
>5 \text { years }\end{array}$ \\
\hline $\begin{array}{l}2 \\
3 \\
4 \\
5 \\
6 \\
7 \\
8 \\
9\end{array}$ & $\begin{array}{r}20 \\
25 \\
10 \\
2 \\
1 \\
1 \\
0 \\
1\end{array}$ & $\begin{array}{r}13 \\
20 \\
6 \\
2 \\
1 \\
1 \\
0 \\
0\end{array}$ & $\begin{array}{l}4 \\
9 \\
4 \\
0 \\
0 \\
1 \\
0 \\
0\end{array}$ & $\begin{array}{r}7 \\
10 \\
4 \\
2 \\
0 \\
0 \\
0 \\
1\end{array}$ \\
\hline Total & 60 & 43 & 18 & 24 \\
\hline
\end{tabular}

TABLE V

SEGREGATION PROPORTION OF SPINAL MUSCULAR ATROPHY BY $A$ PRIORI METHOD

\begin{tabular}{l|c|c|c|c}
\hline & \multicolumn{4}{|c}{ Number of Sibships } \\
\cline { 2 - 5 } & $\begin{array}{c}\text { Total } \\
\text { Data }\end{array}$ & $\begin{array}{c}\text { Ascertainment } \\
\text { Area }\end{array}$ & $\begin{array}{c}\text { Containing } \\
\text { a Child who } \\
\text { Lived } \\
<2 \text { years }\end{array}$ & $\begin{array}{c}\text { Containing } \\
\text { a Child who } \\
\text { Lived } \\
>5 \text { years }\end{array}$ \\
\hline $\begin{array}{l}\text { Number } \\
\text { observed } \\
\begin{array}{l}\text { Number } \\
\text { expected* }\end{array}\end{array}$ & 74 & 55 & 23 & 30 \\
$\begin{array}{l}\text { Standard } \\
\text { error }\end{array}$ & 79.47 & 56.70 & $24 \cdot 12$ & 33.84 \\
\hline $\begin{array}{l}\text { * On the assumptions of simple autosomal recessive inheritance } \\
\text { and complete ascertainment. }\end{array}$
\end{tabular}


years. Though arbitrary, this method was a useful way to test for possible differences in proportions and ratios in the two extremes of the survival range. Table $\mathrm{V}$ shows that in all four categories there is good agreement between the observed values and those expected on the hypothesis of autosomal recessive inheritance with complete ascertainment.

Other genetic observations. For our total group of 91 patients, the disease was not positively diagnosed in any relatives of propositi other than sibs. Three families presented suspicious histories, but no medical confirmation was available.

No marriages of first cousins were reported among the parents of the affected children. Since the sample is small and the frequency of consanguineous marriage in our population is very low, this observation is not contrary to expectation on the basis of autosomal recessive inheritance. Brandt (1950) found that in 4 of 60 sibships $(5.8 \%)$ the parents were first cousins, compared with an estimated $0.7 \%$ in a Danish control population.

Sex ratio. If SMA is transmitted as an autosomal recessive, a normal sex ratio is expected. The sex ratios for the total group and the two subgroups separated on the basis of survival are shown in Table VI. None of these ratios differs significantly from 1:1. This finding is not in agreement with the report that more males than females are affected by both the Werdnig-Hoffmann type and the Kugelberg-Welander type of SMA (Smith and Patel, 1965).

TABLE VI

COMPARISON OF NUMBERS OF MALES AND FEMALES AFFECTED BY SPINAL MUSCULAR DYSTROPHY

\begin{tabular}{l|c|c|c|c|c}
\hline & Males & Females & Total & $x^{2}$ & $\mathrm{p}$ \\
\hline Total sample & 47 & 44 & 91 & $0 \cdot 10$ & $>0.05$ \\
Lived < 2 years & 16 & 16 & 32 & $0 \cdot 00$ & $>0.05$ \\
Lived > 5 years & 19 & 14 & 33 & 0.77 & $>0.05$ \\
\hline
\end{tabular}

Sex and clinical severity. Families have been described in which males had a much more severe disease than their female sibs, while among affected females the severity was fairly uniform (Dubowitz, 1964; Tsukagoshi et al, 1966; Schmid, 1958). In the present study, there were 7 sibships in which a male and a female were affected. In 4 of these, onset of SMA was before the age of 6 months and death occurred in less than a year in both the male and female. In the other 3 families, all the affected children survived more than 5 years, and there was no evidence to suggest that the males were more severely affected. In the pair with the longest 2-J.M.G. survival, the male lived for 11 years and the female for 9 .

Onset age and clinical severity. Though the exact onset age of a progressive disease with insidious onset is impossible to determine, an estimate to the nearest month was obtained from the parents. The onset age distribution is shown in the Figure. The classification 'one month' includes children with symptoms present at birth as well as those recognized up to the end of the first postnatal month.

If the infantile and juvenile forms of SMA are separate entities with characteristic onset ages, bimodality of onset age might be apparent. The onset age distribution shown in the Figure does not indicate the presence of two separate entities.

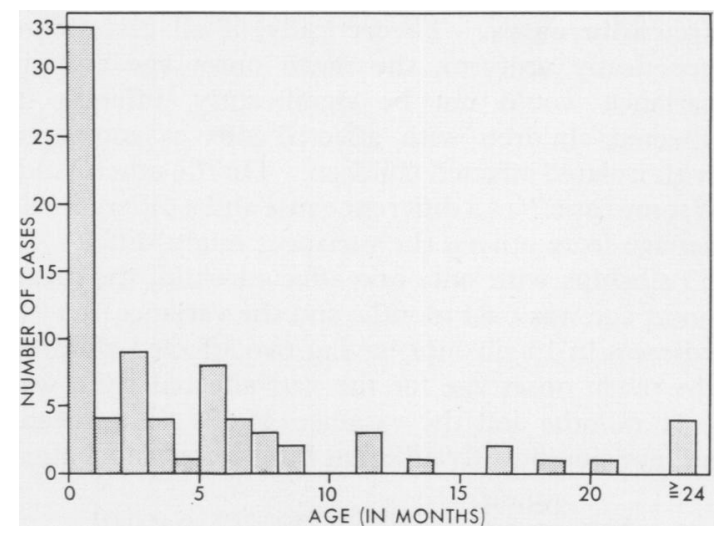

Fig. Onset age of spinal muscular atrophy in months, as reported by the parents, for 79 probands.

Variability of expression. Variability in age at onset of syptoms, interval between onset and death, and age at death were examined by analysis of variance in 13 families having 2 affected sibs each, including 8 families in which both affected sibs were deceased (Table VII). At the $5 \%$ level of significance, there is more variation in onset age between families than within families. The similarity of onset age in sibs may be interpreted either as a consequence of their genetic similarity, ie their possession in common of similar background genes against which the SMA gene manifests itself, or, alternatively, to the possession in common of the same particular gene for the disease, if SMA is genetically heterogeneous. It was not possible to decide between these alternative explanations, as no kindreds were found in which there were 2 or more affected sibships. The age at death and the interval between onset and death showed no significant differences between and within sibships. 
TABLE VII

\section{AGE OF ONSET IN FAMILIES WITH TWO AFFECTED SIBS}

\begin{tabular}{c|c|c}
\hline \multirow{2}{*}{ Sibship Number } & \multicolumn{2}{|c}{ Age of Onset (mth) } \\
\cline { 2 - 3 } & Index Case & Affected Sib \\
\cline { 2 - 3 } & 4 & 1 \\
4 & 1 & 3 \\
5 & 1 & 4 \\
6 & 3 & 2 \\
7 & 20 & 12 \\
8 & 3 & 2 \\
11 & 1 & 3 \\
14 & 6 & 6 \\
22 & 16 & 4 \\
36 & 6 & 1 \\
52 & 1 & 12 \\
61 & 1 & 7 \\
74 & 6 & \\
\hline
\end{tabular}

Comparison of onset age of familial and sporadic cases. Theoretically, if all cases were genetically uniform, the mean onset age and its variance would not be significantly different in affected children with affected sibs as compared with isolated affected children. On the other hand, if some cases had a different cause and a different onset age from others, the variances might differ. In 53 sibships with only one affected child, the mean onset age was 6.84 months and the variance 166.91 , whereas in 13 sibships having two affected children the mean onset age for the first affected child was 5.31 months and the variance 36.40 . The means are not significantly different but the variances are:

$$
\mathrm{F}=\frac{166 \cdot 91}{36 \cdot 40}=4.58, \mathrm{df}(52,12), \mathrm{p}<0.01 .
$$

Assuming that all cases in sibships having more than one affected child are genetic, this observation may indicate that the sporadic cases are not homogeneous, some of them perhaps being phenocopies. The proportion of possible phenocopies with very different onset should be low in view of the evidence for autosomal recessive inheritance.

Ethnic origin. Since many of the families studied were recent immigrants to Canada, the possibility of ethnic differences in the expression of the disease could be explored. Table VIII compares the mean onset age and age at death according to the birthplace of the parents. The mean onset age of patients whose parents were Canadian-born and those whose parents were not Canadian-born showed no significant difference. The number of deceased children was small, but both early and later deaths appeared in both groups. The mean age at death was not significantly different in the two groups. Thus there was no evidence to suggest that SMA is genetically different in different ethnic groups.

Birth order. If SMA is a simple autosomal recessive and there is no environmental influence, there should be no birth order effect. There is no mention of a birth order effect in previous reports.

A total of 59 sibships was tested for birth order effect by the method of Haldane and Smith (1947), which is based on the assumption that if there is no relation between birth order and expression of the trait under study, then every possible sequence of normal and affected sibs is equally likely. All onechild sibships were omitted from consideration. Analysis indicated that later-born sibs were significantly more likely to be affected ( $p<0.01)$.

One possible explanation of this observation is that the data are biased by limitation of family size after the birth of an affected child. If a woman terminates reproduction after having borne an affected child, then in sibships of two or more there would be a greater number of sibships having normal children followed by affected children than sibships with the reverse sequence. Though the sample shows that not every woman ceases childbearing after the birth of an affected child, family limitation may occur often enough to produce the observed birth order effect.

Parental age. In a normal population, increasing parental age accompanies increasing birth rank. In the present study, the average ages of the mothers and fathers of the affected children were compared with the corresponding parental ages for

TABLE VIII

MEAN AGE AT ONSET AND AT DEATH CLASSIFIED ACCORDING TO BIRTHPLACE OF PARENTS

\begin{tabular}{|c|c|c|c|c|c|c|}
\hline \multirow{2}{*}{ Birthplace of Parents } & \multicolumn{3}{|c|}{ Onset } & \multicolumn{3}{|c|}{ Death } \\
\hline & $\begin{array}{c}\text { Number of } \\
\text { Families }\end{array}$ & $\begin{array}{l}\text { Number of } \\
\text { Individuals }\end{array}$ & $\begin{array}{l}\text { Mean } \\
\text { (mth) }\end{array}$ & $\begin{array}{c}\text { Number of } \\
\text { Families }\end{array}$ & $\begin{array}{l}\text { Number of } \\
\text { Individuals }\end{array}$ & $\begin{array}{l}\text { Mean } \\
\text { (mth) }\end{array}$ \\
\hline $\begin{array}{l}\text { Canada } \\
\text { Greece and Italy } \\
\text { British Isles and Europe } \\
\text { Jamaica } \\
\text { Total outside Canada }\end{array}$ & $\begin{array}{r}25 \\
8 \\
9 \\
1 \\
18\end{array}$ & $\begin{array}{r}30 \\
8 \\
11 \\
2 \\
21\end{array}$ & $\begin{array}{l}6 \cdot 60 \\
3 \cdot 88 \\
6 \cdot 45 \\
3 \cdot 50 \\
5 \cdot 19\end{array}$ & $\begin{array}{l}8 \\
3 \\
3 \\
1 \\
7\end{array}$ & $\begin{array}{r}11 \\
3 \\
4 \\
2 \\
9\end{array}$ & $\begin{array}{l}13 \cdot 27 \\
23 \cdot 00 \\
12 \cdot 50 \\
98 \cdot 00 \\
35 \cdot 00\end{array}$ \\
\hline
\end{tabular}


all births in Ontario in the same time period. The average age of the mothers at the birth of their affected children was younger (25.74 years) than the average for total Ontario births (27.04 years) ( $p<$ 0.05 ). The corresponding paternal ages were 28.41 30.30 years, the difference again being significant $(\mathrm{p}<0.01)$. Deliberate limitation of family size could explain this apparent decrease in maternal and paternal ages. It is difficult to think of any alternative explanation for the combined observations of late birth rank and early parental ages.

\section{Discussion}

The sample of cases analysed in the present study appears to satisfy the criteria for autosomal recessive inheritance. There is little doubt that SMA in the 15 sibships with two or more affected members is genetically determined. Even the original cases described by Werdnig and Hoffman were recognized as 'familial'. If dominant inheritance does occur, as reported (Armstrong, Fogelson, and Silberberg, 1966; Tsukagoshi et al, 1966; Zellweger et al, 1969), it must be rare, since no examples were found in the present series.

Though the cases studied conform with the requirements of autosomal recessive inheritance, the possibility of other modes of transmission cannot be eliminated. Since the patients rarely survive to reproductive age, dominant inheritance with reduced penetrance of variable expressivity would not be readily apparent. In addition, the sample is biased by its restriction to patients from a paediatric hospital. If in some cases onset of symptoms did not occur until adult life, these cases would be missed.

In 14 of the 15 sibships with 2 members affected, the affected sibs tended to have similar onset ages and clinical courses. If this were true in all sibships, it would suggest that the Werdnig-Hoffman and Kugelberg-Welander types of SMA were separate disease entities, determined by different genes, possibly but not necessarily allelic. However, the observation of cases with both early and late onset, in one sibship, does not support this interpretation.

Variation of clinical expression within a sibship has been reported by several previous authors. Zellweger et al (1969) reviewed the earlier literature, citing several examples, but considered intrafamilial variability to be much less than interfamilial variability.

Analysis of birth-order effect has indicated that later-born children are more likely than earlierborn to be affected. However, the average age of the parents at the birth of the affected child was significantly younger than the average in the control population. If couples tend to stop having children after the birth of an affected child, both of these observations are explained. The effect of family planning is difficult to assess, but it may be significant that no family in the study had more than 2 affected children. The fact that oral contraceptives have only recently become widely used may be the reason that neither the birth order effect nor the early parental ages have been previously reported.

\section{Summary}

This report describes a genetic and clinical study of spinal muscular atrophy (SMA), seen at the Hospital for Sick Children, Toronto, from 1950 to 1967. The incidence of the disease in an area surrounding Toronto was 1.4 (95\% Poisson confidence interval $=0.3-3 \cdot 8$ ) new cases per year per million of the population. The prevalence was $7 \cdot 4$ (95\% Poisson confidence interval $=4 \cdot 4-11 \cdot 6$ ) per million.

The segregation proportion of the families did not differ significantly from expectation on the basis of autosomal recessive inheritance of a rare gene. No sex differences were found either in the number of affected children or in severity of the disease. Family histories revealed no evidence for affected relatives outside the sibships of the probands. None of the 76 sibships had consanguineous parents. Thus, most cases of spinal muscular atrophy appear to be caused by an autosomal recessive gene, but the possibility of other causes cannot be excluded in our data.

The age at onset was more variable in sporadic cases than in familial ones, suggesting that the sporadic cases are not homogeneous. The parental ages of mothers and fathers of SMA patients were both younger than the corresponding parental ages in the general population of Ontario. A test for birth-order effect indicated that later-born children were more likely to be affected than their earlierborn sibs. Both of these phenomena may be due to artificial limitation of family size.

This study was supported in part by the Muscular Dystrophy Association of Canada.

\section{REFERENCES}

Armstrong, R. M., Fogelson, M. H., and Silberberg, D. H. (1966). Familial proximal spinal muscular atrophy. Archives of Neuro$\log y, 14,208-212$.

Becker, P. E. (1963). Atrophia musculorum spinalis pseudomyopathica. Hereditäre neurogene proximale Amyotrophie von Kugelberg und Welander. Zeitschrift für Menschliche Vererbungsund Konstitutionslehre, 37, 193-220.

Brandt, S. (1950). Werdnig-Hoffmann's Infantile Progressive Muscular Atrophy, Clinical Aspects, Pathology, Heredity and Relation to 
Oppenheim's Amyotonia Congenita and other Morbid Conditions with Laxity of foints or Muscles in Infants. Munksgaard, Copenhagen. Dubowitz, V. (1964). Infantile muscular atrophy: a prospective study with particular reference to a slowly progressive variety. Brain, 87, 707-718.

Haldane, J. B. S. and Smith, C. A. B. (1947). A simple exact test for birth-order effect. Annals of Eugenics, 14, 117-124.

Hogben, L. T. (1946). An Introduction to Mathematical Genetics. Norton, New York.

Hoffmann, J. (1892). Ueber chronische spinale Muskelatrophie im Kindesalter, auf familiärer Basis. Deutsche Zeitschrift für Nervenheilkunde, 3, 427-470.

Kugelberg, E. and Welander, L. (1956). Heredofamilial juvenile muscular atrophy simulating muscular dystrophy. Archives of Neurology and Psychiatry, 75, 500-509.

Ontario (Province of) Vital Statistics; Report of the Registrar General, 1955-1965.

Research Group on Neuromuscular Diseases (1968). Classification of the neuromuscular disorders. Appendix A to the Minutes of the Meeting of the Research Group on Neuromuscular Diseases, held in Montreal, Canada, on 21 September, 1967. Fournal of the Neurological Sciences, 6, 165-177.

Schmid, P. C. (1958). Beitrag zum Krankheitsbild der infantilen progressiven spinalen Muskelatrophie nach Werdnig-Hoffmann. Zeitschrift für Kinderheilkunde, 81, 13-25.

Smith, J. B. and Patel, A. (1965). The Wohlfart-KugelbergWelander disease. Neurology (Minneapolis), 15, 469-473.

Tsukagoshi, H., Sugita, H., Furukawa, T., Tsubaki, T., and Ono, E. (1966). Kugelberg-Welander syndrome with dominant inheritance. Archives of Neurology, 14, 378-381.

Werdnig, G. (1891). Zwei frühinfantile hereditäre Fälle von progressiver Muskelatrophie unter dem Bilde der Dystrophie, aber auf neurotischer Grundlage. Archiv für Psychiatrie und Nervenkrankheiten, 22, 437-480.

Zellweger, H., Schneider, H. J., Schuldt, D. R., and Mergner, W. (1969). Heritable spinal muscular atrophies. Helvetica Paediatrica Acta, 24, 92-105. 